\title{
Epitaxial Growth of Fe Thin Films on MgO Single-Crystal Substrates
}

\author{
Kouhei Shikada, Kenji Tabuchi, Mitsuru Ohtake, Fumiyoshi Kirino*, and Masaaki Futamoto \\ Faculty of Science and Engineering, Chuo University, 1-13-27 Kasuga, Bunkyo-ku, Tokyo 112-8551, Japan \\ *Graduate School of Fine Arts, Tokyo National University of Fine Arts and Music, 12-8 Ueno-koen, Taito-ku, Tokyo 110-8714, Japan
}

Fe thin films were prepared on $\mathrm{MgO}(100), \mathrm{MgO}(110)$, and $\mathrm{MgO}(111)$ substrates by UHV-MBE. The film growth structure and the magnetic properties were investigated. In-situ RHEED observation showed that epitaxial Fe thin film with the $(100)_{b c c},(211)_{b c c}$, and (110) bcc planes parallel to the substrate surface grew on respective $\mathrm{MgO}$ substrates at elevated temperatures. The $\mathrm{Fe}(100)_{\text {bcc }}$ film formed on $\mathrm{MgO}(100)$ is a single crystal, while the $\mathrm{Fe}(211)_{\mathrm{bcc}}$ films on $\mathrm{MgO}(110)$ consists of two domains with a twin relationship. The $\mathrm{Fe}(110)_{\text {bcc }}$ film on $\mathrm{MgO}(111)$ consists of two types of sub-domains with Nishiyama-Wasserman and Kurdjumov-Sachs epitaxial orientation relationships. A $0.3 \%-0.5 \%$ reduction of the lattice spacing perpendicular to the substrate surface was observed by X-ray diffraction for $\mathrm{Fe}$ thin films prepared at a substrate temperature of $200{ }^{\circ} \mathrm{C}$. This reduction decreases with increasing the substrate temperature for the $\mathrm{MgO}(100)$ and (111) substrates. The in-plane magnetic anisotropy measured for three epitaxial films reflects the magneto-crystalline anisotropy of bulk Fe crystal.

Key words: Fe thin film, epitaxial growth, $\mathrm{MgO}(100), \mathrm{MgO}(110), \mathrm{MgO}(111), \mathrm{MBE}, \mathrm{RHEED}$

\section{$\mathrm{MgO}$ 単結晶基板上における $\mathrm{Fe}$ 薄膜のエピタキシャル成長 \\ 鹿田昂平・田㴊健司 ·大竹充 $\cdot$ 桐野文良 ${ }^{*} \cdot$ 二本正昭 \\ 中央大学理工学部, 東京都文京区春日 1- 13-27 ( T 112- 8551) \\ "東京藝術大学大学院美術研究科, 東京都台東区上野公園 12-8 (₹ 110-8714)}

\section{1.はじめに}

鉄 (Fe) は高い磁気モーメントを持つ代表的な磁生材料であり， Fe及ひFe合金薄膜力磁気ヘッドなどの磁気応用デバイスに用いら れている.磁気応用デバイスの可能性検討においては薄膜材料の 基本磁気特性を知ることが必要である. 基本磁気特性を調べるた めには膜構造力制御されたエピタキシャル薄膜か洧用であり，エ ピタキシャル薄膜を用いて結晶磁気異方性エネルギーやダンピン ク定数などの検討がなされている1,2) .これまで(100) ${ }^{3-8)}$,(110) ${ }^{9-11}$ 面 のMgO及びGaAs基板を用いてFe薄膜のエピタキシャル成長か試 みられ，結晶構造や磁気特性などか調べられている．薄膜の微細 構造や磁気特性は基板の表面状態や膜の形成条件により変化する ことか知られている．しかしながら，同樣な実験条件で複数の結 晶面の同一種基板を用いてエピタキシャルFe薄膜を作製した報告 は殆ど知られていない，本研究では, $\mathrm{MgO}(100),(110)$, 及び(111) 単結晶基板を用いて, 同樣の実験条件でエピタキシャルFe薄膜の 作製を試みた.Fe薄膜の形成過程を反射高速電子回折 (RHEED) により光の場観察し，膜の成長機構を調べるとともに，基板面や 基板温度などの形成条件かFe薄膜の表面形態や磁気特性に及ぼす 効果について系統的に調へた。

\section{2. 実験方法}

試料の作製には到達真空度 $3 \times 10^{-8}$ Pa以下の超高真空分子 線エピタキシー (UHV-MBE) 装置を用いた . 基板として 表面研磨した $\mathrm{MgO}(100)$ ，(110），及び(111)を用いた . 基板 表面の清浄化を目的に製膜前に超高真空中で $400{ }^{\circ} \mathrm{C} \times 1 \mathrm{hr}$ の熱処理を行った. $\mathrm{MgO}$ 基板表面をRHEEDで観察し，光 れぞれの単結晶基板面に対応する回折スポットが観察され ることを確認した後, $\mathrm{Fe}$ 薄膜形成を行った 基板温度は 200

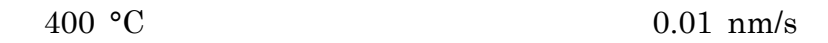
基板上に $20 \mathrm{~nm}$ の $\mathrm{Fe}$ 薄膜を形成した。

膜形成中の薄膜表面構造をRHEEDにより产の場観察を 行った . 薄膜の構造は $\mathrm{Cu}-K_{\alpha}$ 線 $(\lambda=0.15418 \mathrm{~nm})$ を用い たX線回折 (XRD) により評価し, 表面形態は原子間力顕 微鏡 $(\mathrm{AFM})$ を用いて観察した。磁気特性評価には試料振 動型磁力計 (VSM) を用いた。

\section{3. 結果と考察}

\section{3. $1 \mathrm{MO}$ ( 100) 基板上に形成した Fe 薄膜}

$\mathrm{MgO}(100)$ 基板上においてエピタキシャル Fe 薄膜か得られた . Fig. 1 に表面処理した後の $\mathrm{MgO}(100)$ 基板及びこの基板に基板温 度 $300{ }^{\circ} \mathrm{C}$ で形成した $20 \mathrm{~nm}$ 厚の $\mathrm{Fe}$ 薄膜試料から得られた RHEED パターンを示す. エピタキシャル方位関係は以下の通り であった .

\section{$\mathrm{Fe}(100)[011]_{\text {boc }} / / \mathrm{MgO}(100)[001]$}

Fe薄膜はFig. 2 に示すようにMgO(100)基板の結晶面に対して $45^{\circ}$ 回転した関係でエピタキシャル成長しており，このときの $\mathrm{MgO}[001]$ 方向の格子ミスマッチは-3.6\%である.なお , ミスマッ チの值はバルクFe結晶の格子定数を用いて求めた值である .Fig. 3

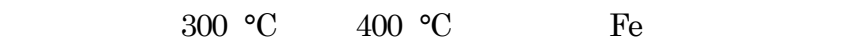
RHEEDパターンを示す. 形成初期過程から $\mathrm{Fe}(100)_{\text {bock }}$ に対応する

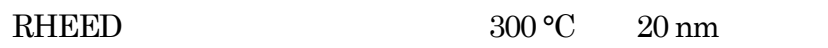
て殆どRHEEDパターン形状は変化していない．これに対し，基 板温度を $400{ }^{\circ} \mathrm{C} と し た$ 場合, 膜厚が $10 \mathrm{~nm}$ 付近から $c(2 \times 2)$ の表面 再構成 ${ }^{12}$, 13) を示すRHEEDパターンか現れ始め,膜厚の増加ととも に鮮明になった。

Fig. 4 に基板温度 $200^{\circ} \mathrm{C}, 300^{\circ} \mathrm{C}$ 及び $400^{\circ} \mathrm{C}$ て形成した $20 \mathrm{~nm}$ 


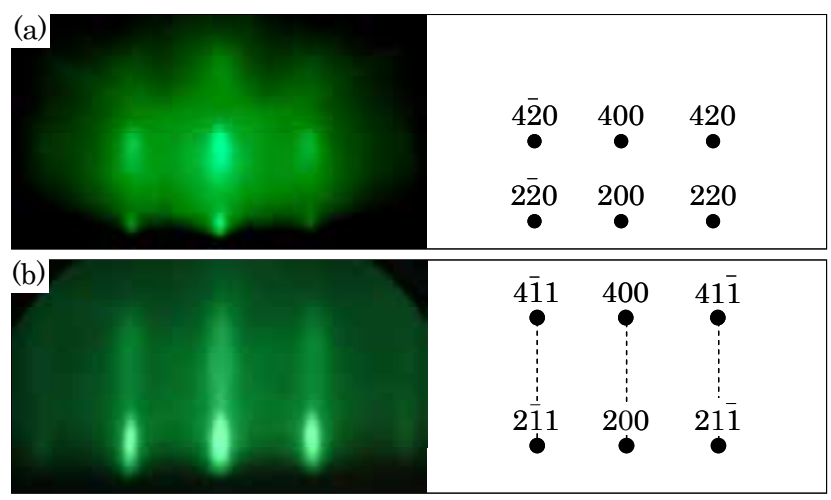

Fig. 1 RHEED patterns observed for (a) $\mathrm{MgO}(100)$ substrate and (b) Fe thin film deposited at $300{ }^{\circ} \mathrm{C}$. The incident electron beam is parallel to the $\mathrm{MgO}$ [001] direction.

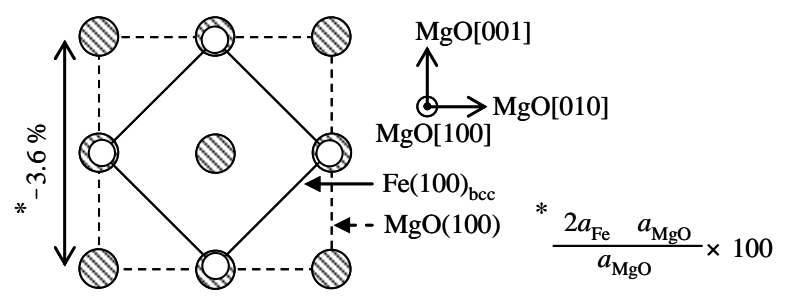

Fig.2 Epitaxial orientation relationship and lattice mismatch value of $\mathrm{Fe}(100)_{\mathrm{bcc}} / / \mathrm{MgO}(100)$.

厚のFe薄膜のXRDパターンを示す . 基板温度が低い場合， $\mathrm{Fe}(200)_{b a c}$ ピークの高角側へのシフトか認められる . 基板温度 $200{ }^{\circ} \mathrm{C}$ て形成したFe薄膜の結晶格子は ,バルクFeに比へて膜面垂 直方向か喲 $0.5 \%$ 収縮していることが分かつた 基板温度を $400^{\circ} \mathrm{C}$ まで上昇させると，バルク $\mathrm{Fel}$ に近し格子間融をとる傾向力認めら れた .

Fig. 5 にMgO(100)基板上に形成したエピタキシャルFe薄膜の AFM像を示す . Fe薄膜は島状 (Volmer-Weber ${ }^{14)}$ ) 樣式でエピタ キシャル成長しており，基板温度が $200^{\circ} \mathrm{C} \sim 400^{\circ} \mathrm{C}$ に上昇するに つれて , 粒径が $17 \mathrm{~nm}$ から $32 \mathrm{~nm}$ 程度に大きくなっているが , 表 面粗さ $R_{a}$ は(a) $1.7 \mathrm{~nm}$,(b) $1.3 \mathrm{~nm}$, (c) $1.4 \mathrm{~nm}$ と小さく，比較的平 坦性の良い膜力形成されているのか汾かる.

Fig. 6 に磁気特性を示す.いずれの基板温度においても飽和磁化 值はバルクFeと同樣であり,100e程度の低い保磁力を示した.面 内の磁気異方性はFe[001]boc方向力磁化容易軸となっており，Feの 結晶磁気異方性を反映していることが分かった . 基板温度を 200 〜 400 ${ }^{\circ} \mathrm{C}$ 範囲て変えて作製した試料の磁気特性はしずれもほぼ 同㭏であった 。

\section{3. $2 \mathrm{MO}$ (110) 基板上に形成した $\mathrm{Fe}$ 薄膜}

$\mathrm{MgO}(110)$ 基板上においてエピタキシャルFe薄膜が得られた . Fig. 7 にMgO[001]及び[110]方位と平行に電子ビームを入射して 観察した基板と, 基板温度 $300^{\circ} \mathrm{C}$ て形成した $20 \mathrm{~nm}$ 厚のFe薄膜の RHEEDパターンを示す. $\mathrm{MgO}\left[\begin{array}{l}1 \\ 1\end{array} 0\right]$ 方位から観察した (a)

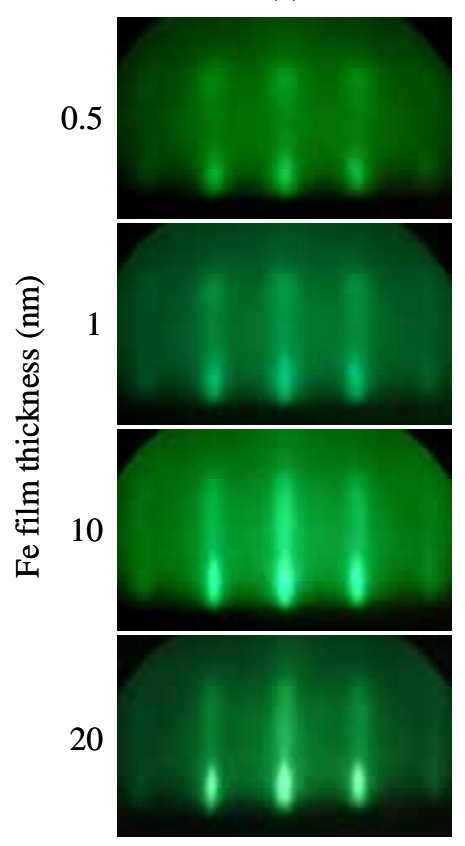

(b)

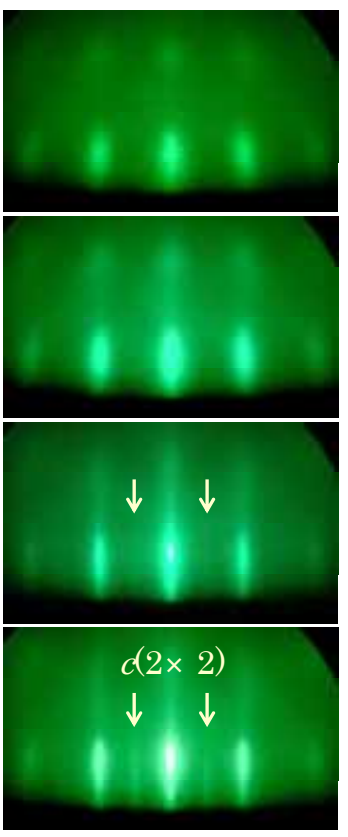

Fig. 3 RHEED patterns of Fe films observed during film deposition at (a) $300{ }^{\circ} \mathrm{C}$ and (b) $400{ }^{\circ} \mathrm{C}$. The incident electron beam is parallel to the MgO[001] direction. The arrows show surface reconstruction.

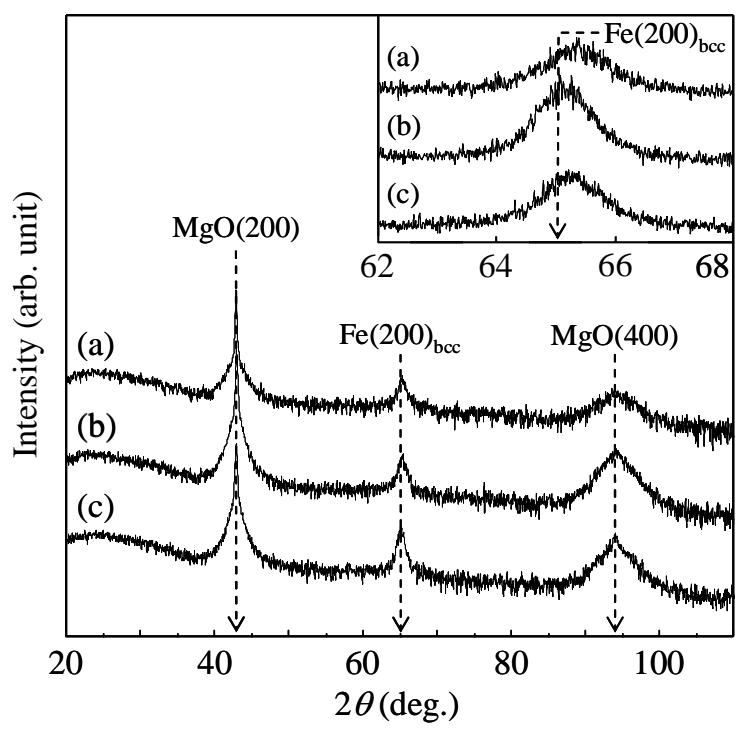

Fig. 4 XRD spectra of Fe thin films grown on $\mathrm{MgO}(100)$ substrates at (a) $200{ }^{\circ} \mathrm{C}$, (b) $300^{\circ} \mathrm{C}$, and (c) $400{ }^{\circ} \mathrm{C}$. The intensity is shown in a logarithmic scale.

RHEEDパターンでは判別できないが, $\mathrm{MgO}[001]$ 方位から観察し たRHEEDパターンで，Fig. 7(b)中でAとBて区別して示した 2 種類のドメインからの反射か重複して現れている.MgO(110)基板 上に成長したFe薄膜は，Fig. 8(a)に示すような $\mathrm{Fe}(211)_{b c c}$ 面が $\mathrm{MgO}(110)$ 基板に対して膜面垂直方向に互いに $180^{\circ}$ 回転した関係 

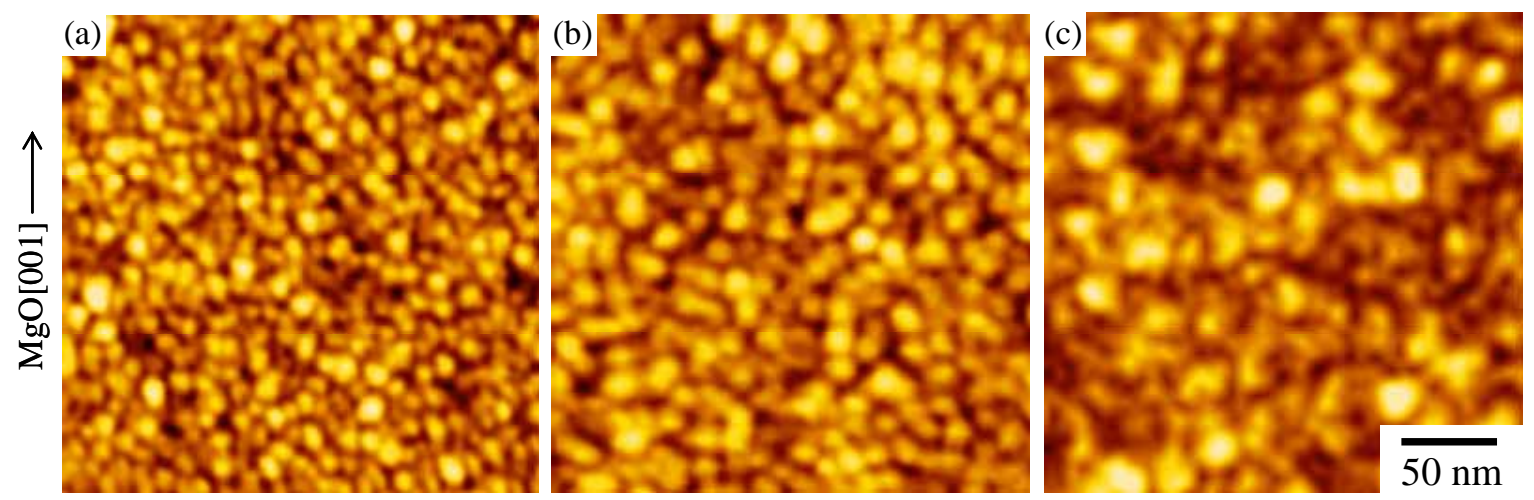

Fig. 5 AFM images of $\mathrm{Fe}$ thin films deposited on $\mathrm{MgO}(100)$ substrates at (a) $200{ }^{\circ} \mathrm{C}$, (b) $300{ }^{\circ} \mathrm{C}$, and (c) $400{ }^{\circ} \mathrm{C}$.

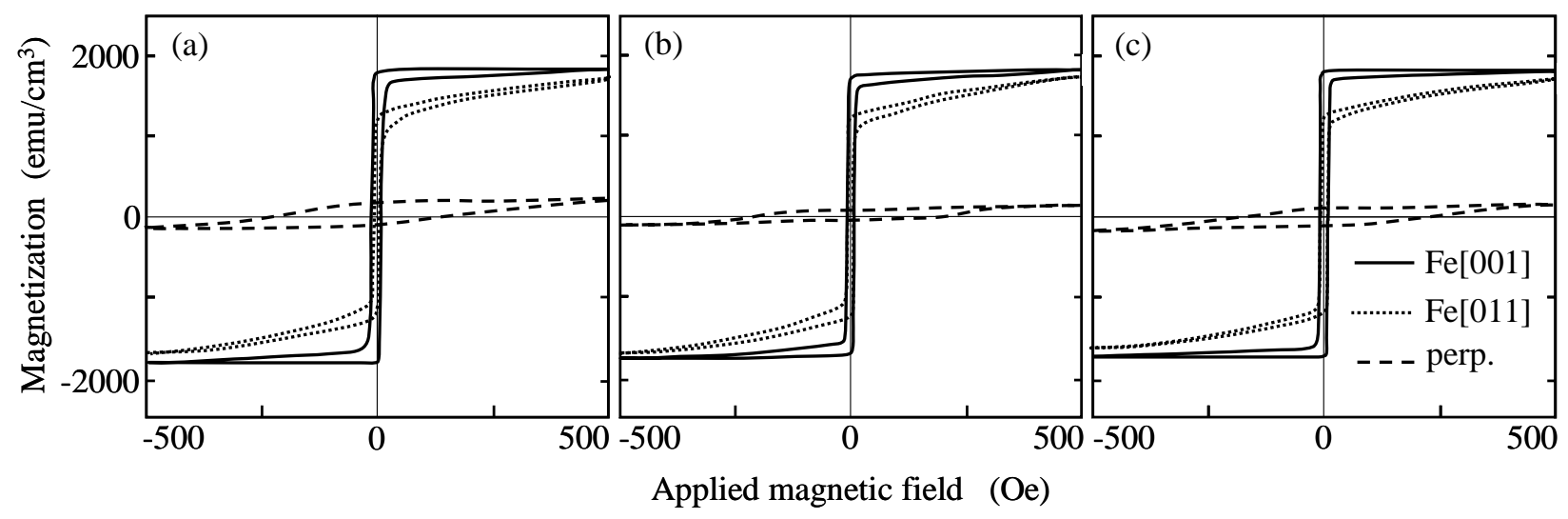

Fig. 6 Magnetization curves of Fe thin films deposited on $\mathrm{MgO}(100)$ substrates at (a) $200{ }^{\circ} \mathrm{C}$, (b) $300{ }^{\circ} \mathrm{C}$, and $400{ }^{\circ} \mathrm{C}$.

をもつ双結晶から構成されていることが分かった .エピタキシャ ル方位関係は以下の通りである。

\section{A: $\mathrm{Fe}(211)[1 \overline{1} \overline{1}]_{b c c} / / \mathrm{MgO}(110)[1 \overline{1} 0]$ \\ B: $\mathrm{Fe}(211)[\overline{1} 11]_{b c c} / / \mathrm{MgO}(110)[1 \overline{1} 0]$}

Fig. 8(b)に示すように , Fe薄膜のMgO基板に対する格子ミスマッ チはMgO[001]方向では-3.6\%と小さいが, $\mathrm{MgO}[1 \overline{1} 0]$ 方位で $-16.5 \%$ ときな值となっている.このような双結晶のエピタキシ ヤル成長はCr薄膜を $\mathrm{MgO}(110)$ 基板上に形成した場合においても 報告されており15)， $\mathrm{Cr}(211)_{\mathrm{bcc}} / \mathrm{MgO}(110)$ 界面においても $\mathrm{MgO}$ [110]方位に-16.2\%の大きなミスマッチか存在する.弚のミスマッ チは，界面において $\mathrm{MgO}$ 格子 5 倍周期に対してCr格子 6 倍周期で マッチングすることにより緩和されることが, 高分解能透過電子 顕微鏡を用いた断面構造解析により観察されている16) 本研究て扱

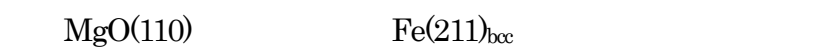
関係でミスマッチカ緩和されていることが考えられる．この場合， $\mathrm{MgO}[110]$ 方位に対してMgO格子 5 倍周期に対するFe格子 6 倍周 期のミスマッチは

$$
\frac{(\sqrt{3} / 2) a_{\mathrm{Fe}} \times 6-(\sqrt{2} / 2) a_{\mathrm{MgO}} \times 5}{(\sqrt{2} / 2) a_{\mathrm{MgO}} \times 5} \times 100=0.2 \%
$$

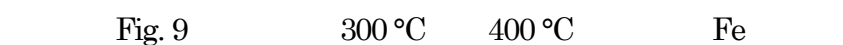
一連のRHEEDパターンを示す. 膜厚 $0.5 \mathrm{~nm}$ のFeを形成した初期 過程の段皆から $\mathrm{Fe}(211)_{\text {bock }}$ 対応するRHEEDパターンか観察され

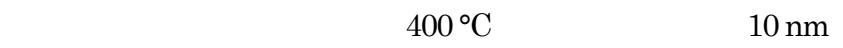
付近からFe[110]boc方向にストリークか観察されており，Fe(110)boc ファセット面か形成されていることか汾かる.

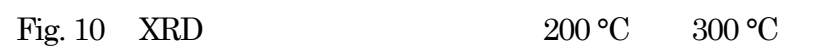
作製した試料ては $\mathrm{Fe}(211)$ boc反躬強度は低いが, 基板温度 $400^{\circ} \mathrm{C} に$ なると強し $\mathrm{Fe}(211)_{\mathrm{bcc}} 反$ 射か観察されている. また，すへてて基板 温度においてFe(211)boピークの高角側へシフトが見受けられる。 基板温度 $200{ }^{\circ} \mathrm{C}$ て形成したFe薄膜の(211)bco面間翮はバルクFeに 比べ $0.3 \%$ 小さい值となった .

Fig. 11に $\mathrm{MgO}$ (110)基板上に形成したFe薄膜の表面形態を示す . $\mathrm{Fe}$ 薄膜は $\mathrm{MgO}(100)$ 基板の場合と同樣に, Volmer-Weber 樣式で エピタキシャル成長しており, 基板温度 $200{ }^{\circ} \mathrm{C}$ 及び $300{ }^{\circ} \mathrm{C}$ て形 成した $\mathrm{Fe}$ 薄膜では粒径力喲 $30 \mathrm{~nm}$ の島状形態となっている. 基 板温度 $400^{\circ} \mathrm{C}$ ては島の大きさか増加するとともに，表面に細かい 粒子か形成されていることか汾かる. また, 基板温度 $400^{\circ} \mathrm{C}$ て形 成した $\mathrm{Fe}$ 薄膜の表面形態を $\mathrm{AFM}$ 像の断面プロファイル法を用い て解析した結果 (Fig. 12(c)), 特定の結晶面から構成されたファセ 

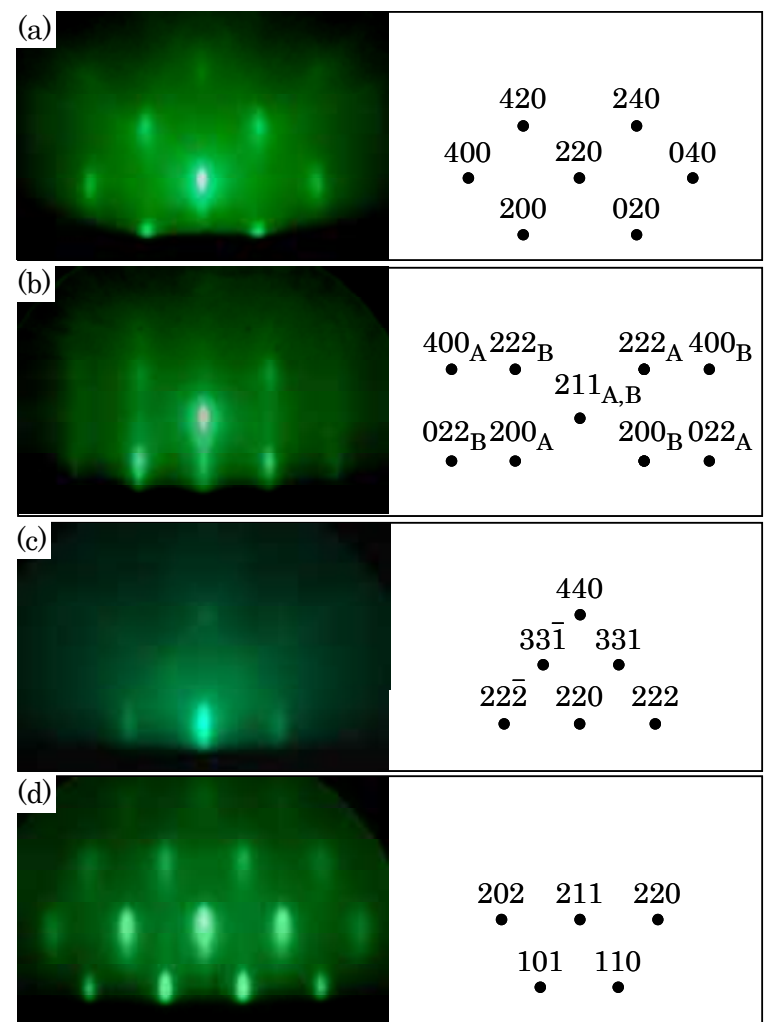

Fig. 7 RHEED patterns observed for $\mathrm{MgO}(110)$ substrate, (a), (c), and for Fe thin film deposited at $300^{\circ} \mathrm{C}$, (b), (d). The incident electron beam is parallel to the $\mathrm{MgO}[001]$ direction, (a), (b), and parallel to the $\mathrm{MgO}[1 \overline{1} 0]$ direction, (c), (d).

(a)

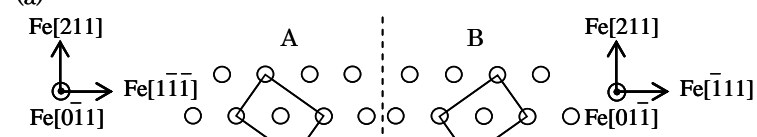

$\mathrm{Fe}[011] \quad O$ Q

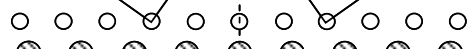

$\theta \otimes \theta \otimes \otimes \otimes \otimes \theta$

$\mathrm{MgO}[110]$

$$
\theta \otimes \otimes \otimes \otimes \otimes \otimes \otimes \theta
$$

(b)

$$
\underset{\mathrm{MgO}[001]}{\longrightarrow} \mathrm{MgO}[1 \overline{1} 0]
$$

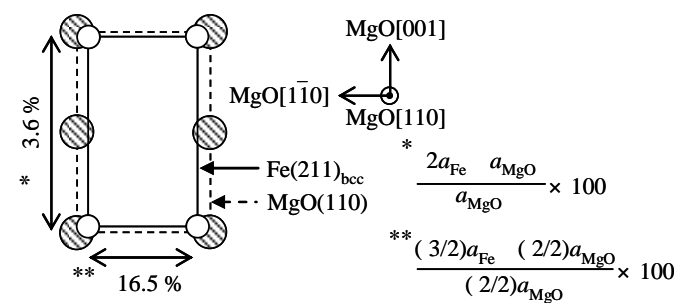

Fig. 8 Epitaxial orientation relationship and mismatch value of $\mathrm{Fe}(211)_{\mathrm{bcc}} / / \mathrm{MgO}(110)$.

ット面か観察された .このファセット面はRHEED観察により確 認された $\mathrm{Fe}(110)_{b c c}$ ファセット面に対応しているものと解釈される .

Fig. 13 に磁気特性を示す. 飽和磁化值はいずれの基板温度にお (a)
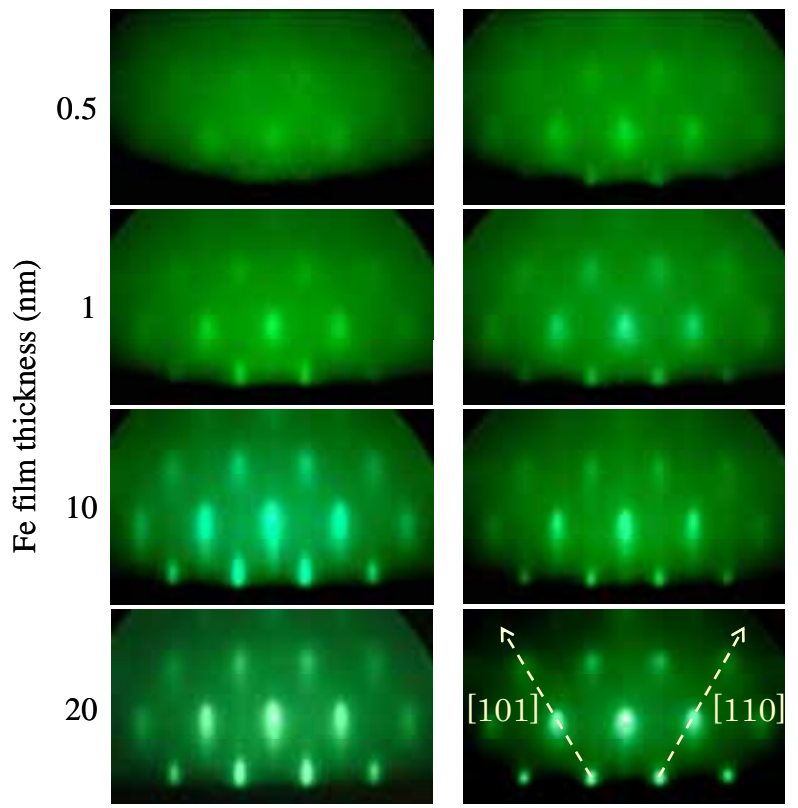

Fig. 9 RHEED patterns of Fe films observed during film deposition at (a) $300{ }^{\circ} \mathrm{C}$ and (b) $400{ }^{\circ} \mathrm{C}$. The incident electron beam is parallel to the MgO[110] direction.

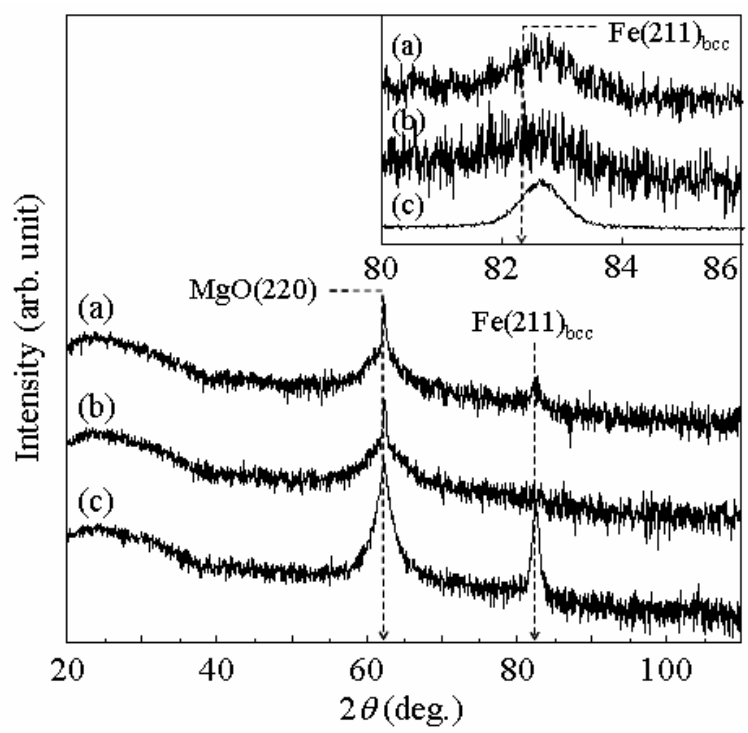

Fig. 10 XRD patterns of Fe thin films grown on $\mathrm{MgO}(110)$ substrates at (a) $200{ }^{\circ} \mathrm{C}$, (b) $300{ }^{\circ} \mathrm{C}$, and (c) $400{ }^{\circ} \mathrm{C}$. The intensity is shown in a logarithmic scale.

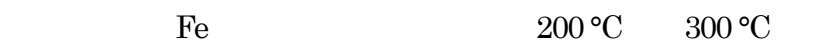
成したFe薄膜は 30 Oe以下の保磁力を示し, $400^{\circ} \mathrm{C}$ て形成したFe 薄膜の保磁力は 10 Oeとさらに低し值を示した . Fig. 10 に示す

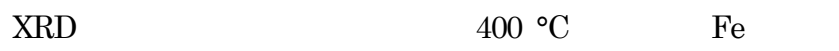
$\mathrm{Fe}(211)$ boc反射の強度力増大している. 基板温度を上げることて結 晶性の良いエピタキシャルFe薄膜力得られ，保磁力が咸少したも のと考えられる Fe薄膜の面内の磁気異方性を調へた二結果 ,Fig. 14 

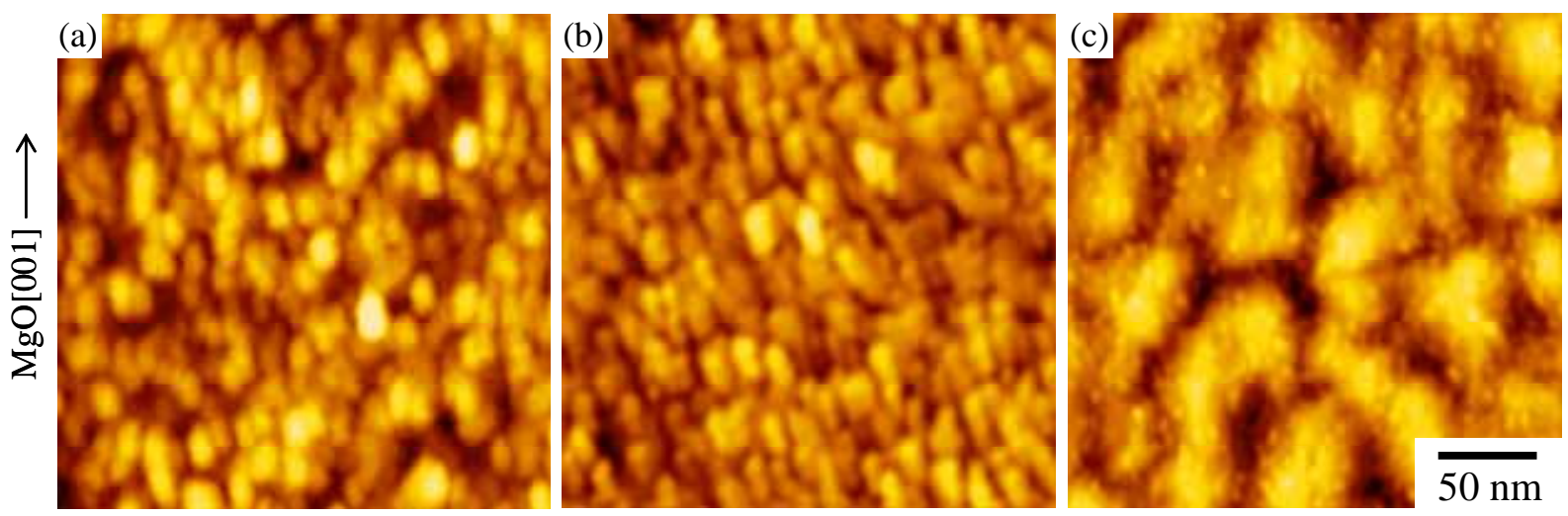

Fig. 11 AFM images of Fe thin films deposited on $\mathrm{MgO}(110)$ substrates at (a) $200{ }^{\circ} \mathrm{C}$, (b) $300{ }^{\circ} \mathrm{C}$, and (c) $400{ }^{\circ} \mathrm{C}$.
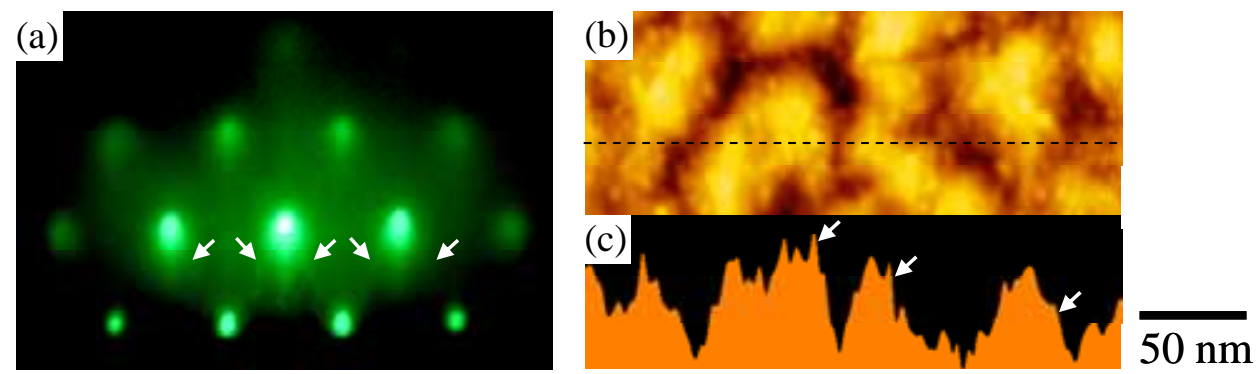

Fig. 12 RHEED pattern (a) and AFM image (b) of $20 \mathrm{~nm}$ thick $\mathrm{Fe}(211)$ epitaxial film deposited on $\mathrm{MgO}(110)$ substrate at $300^{\circ} \mathrm{C}$. The incident electron beam of RHEED (a) is parallel to the MgO[110] direction. The arrows in (a) show the streak directions. (c) cross-sectional profile along the doted line in the AFM image (b). The arrows in (c) are presumably corresponding to the RHEED streaks shown in (a).

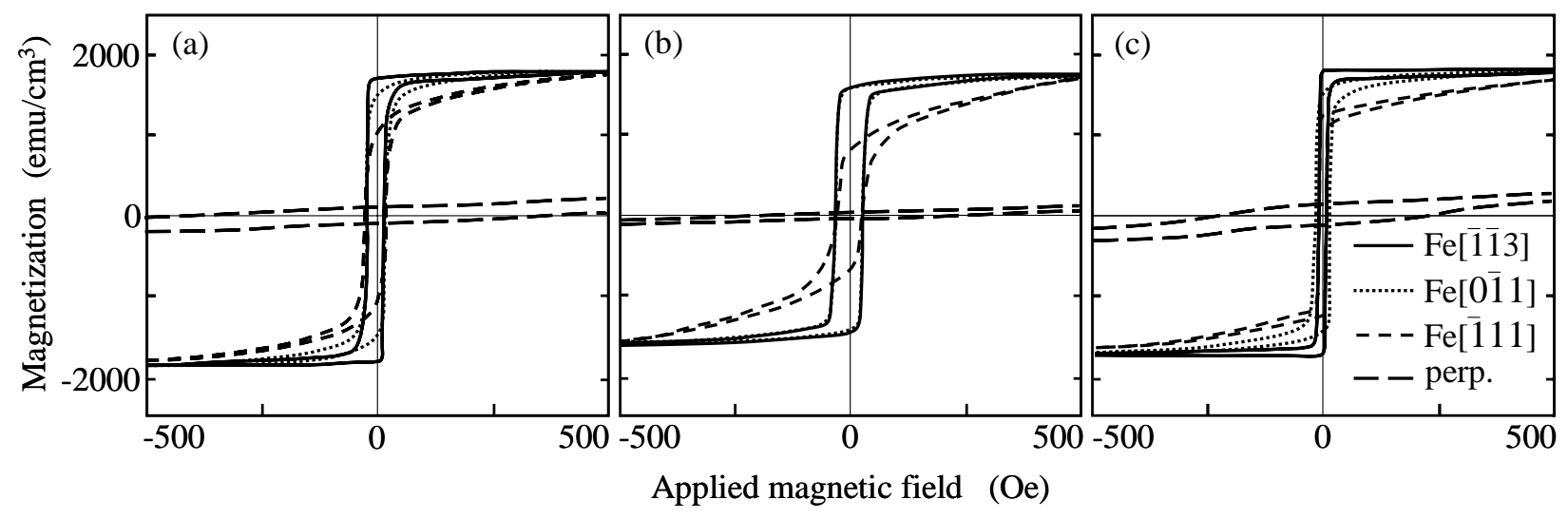

Fig. 13 Magnetization curves of Fe thin films deposited on $\mathrm{MgO}(110)$ substrates at (a) $200{ }^{\circ} \mathrm{C}$, (b) $300{ }^{\circ} \mathrm{C}$, and (c) $400{ }^{\circ} \mathrm{C}$.

に示すように ,バルクFeにおいて磁化容易軸である[010]方位を面 内に倒した[11ㅣㄱㄱ方位力磁化容易方向となっており，Feの結晶磁気 異方性を反映しているものと解釈できる .

\section{$3.3 \mathrm{~N} \&$ Q 111) 基板上に形成した Fe 薄膜}

$\mathrm{MgO}(111)$ 基板上においてもエピタキシャルFe薄膜か得られた .

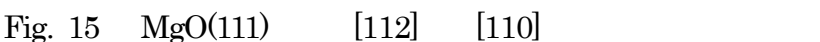
ムを入射して観察した基板と, 光の上に形成した $20 \mathrm{~nm}$ 厚のFe薄
膜から得られたRHEEDパターンを示す .Fig. 15(b)及ひFig. 15(d) に示すRHEEDパターンは 2 種類の反射か重複しており，内側と 外則の 2 つの反射ストリークに分離できる .これらの反射ストリ 一クは，乥れ光れfcc(111)面上におけるFe(110) boc薄膜成長て知られ る結晶方位関係Nishiyama-Wasserman $\left.{ }^{17}, 18\right)(\mathrm{NW})$ と Kurdjumov-Sachs ${ }^{19)}$ (KS) に対応している. Fig. 15(b)の内側と Fig. 15(d)の外側に観察されているRHEED反射は, Fig. 16(a)に 


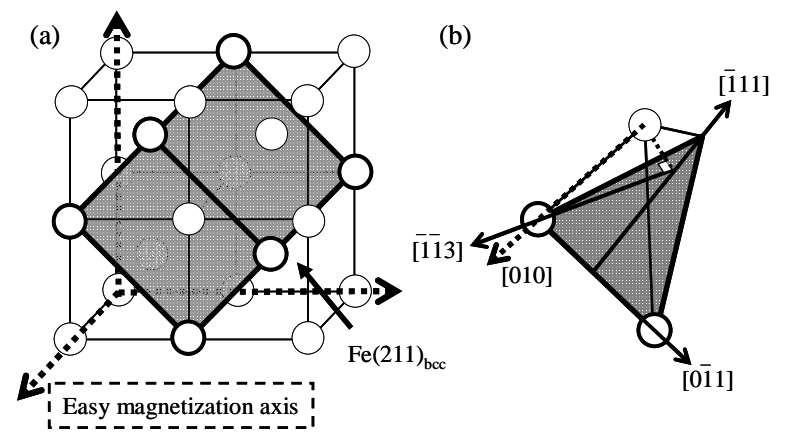

Fig. 14 Structure of $\mathrm{Fe}(211)$ plane and easy magnetization direction.

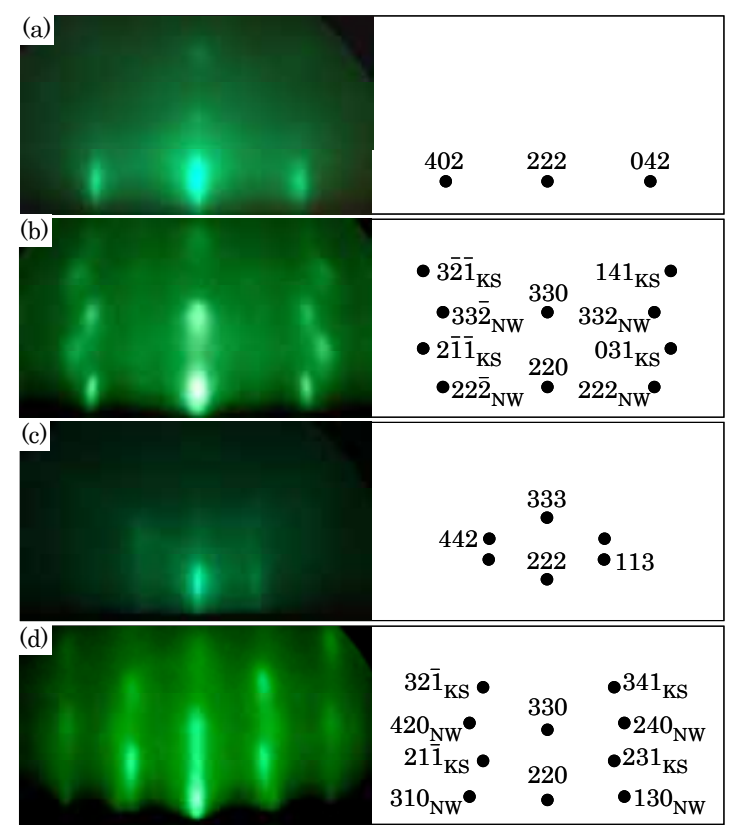

Fig. 15 RHEED patterns observed for $\mathrm{MgO}(111)$ substrate, (a), (c), and for Fe thin film deposited at $300{ }^{\circ} \mathrm{C}$, (b), (d). The incident electron beam is parallel to the $\mathrm{MgO}[112]$ direction, (a), (b), and parallel to the MgO[110] direction, (c), (d).

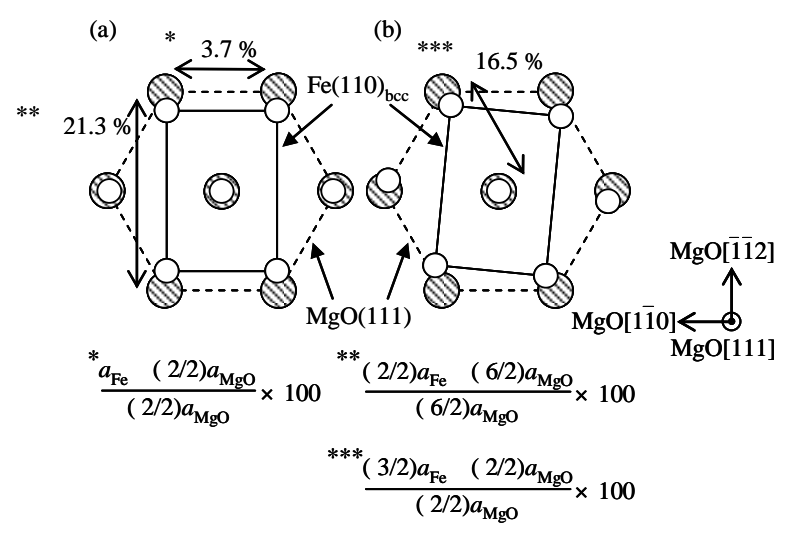

Fig. 16 (a) NW and (b)KS epitaxial orientation relationships and the lattice mismatch value of $\mathrm{Fe}(110)_{\text {bcc }} / / \mathrm{MgO}(111)$.

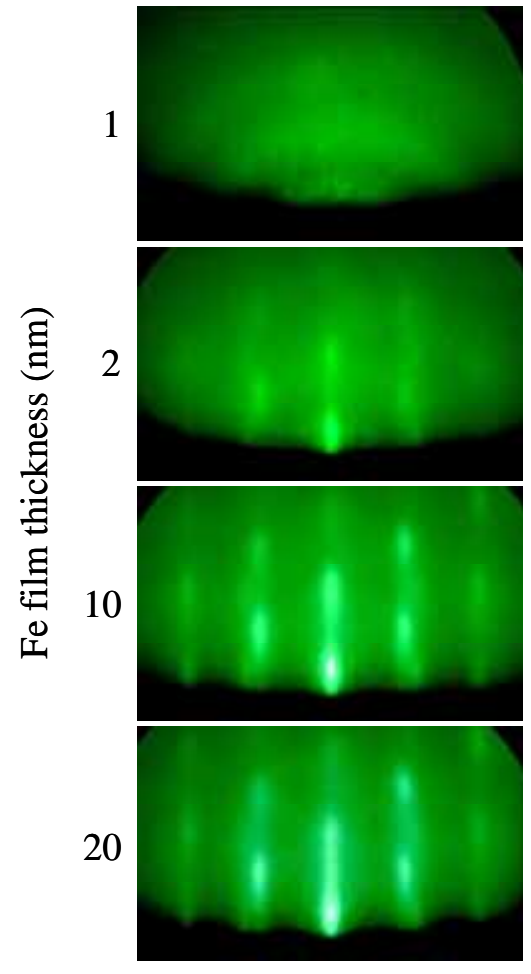

Fig. 17 RHEED patterns of Fe film observed during film deposition at $300^{\circ} \mathrm{C}$. The incident electron beam is parallel to the $\mathrm{MgO}[110]$ direction.

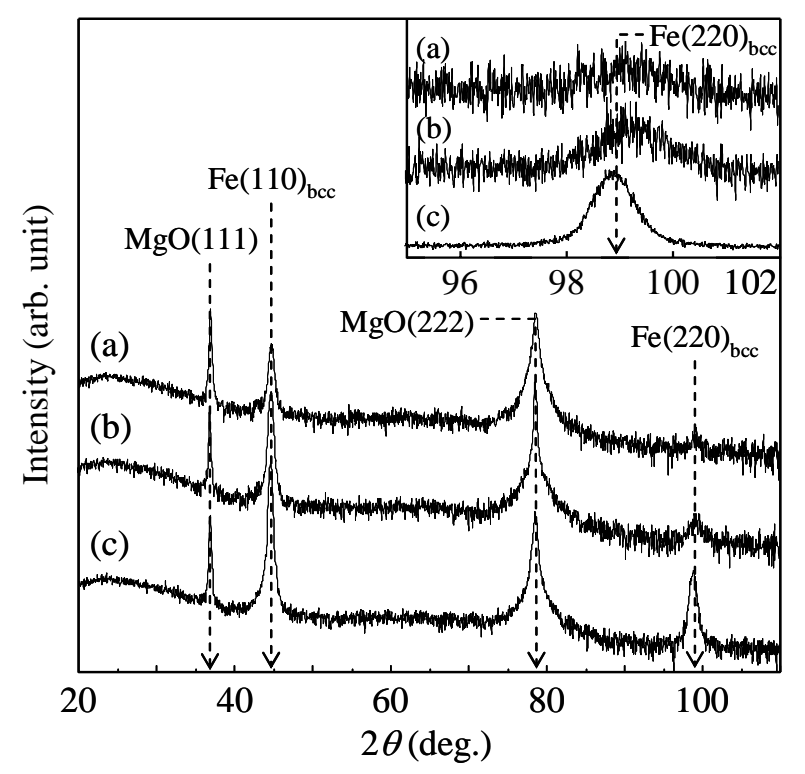

Fig. 18 XRD patterns of $\mathrm{Fe}$ thin films grown on $\mathrm{MgO}(111)$ substrates at (a) $200{ }^{\circ} \mathrm{C}$, (b) $300{ }^{\circ} \mathrm{C}$, and (c) $400{ }^{\circ} \mathrm{C}$. The intensity is shown in a logarithmic scale.

示す形でMgO基板とマッチングするNW関係に対応する . 一方， Fig. 15(b)の外側とFig. 15(d)の内側に観察されるRHEED反射は， Fig. 16(b)に示すようにNW関係から面内で5゚程度傾いた状態でマ

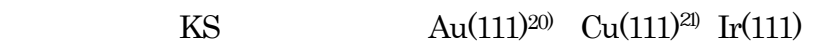



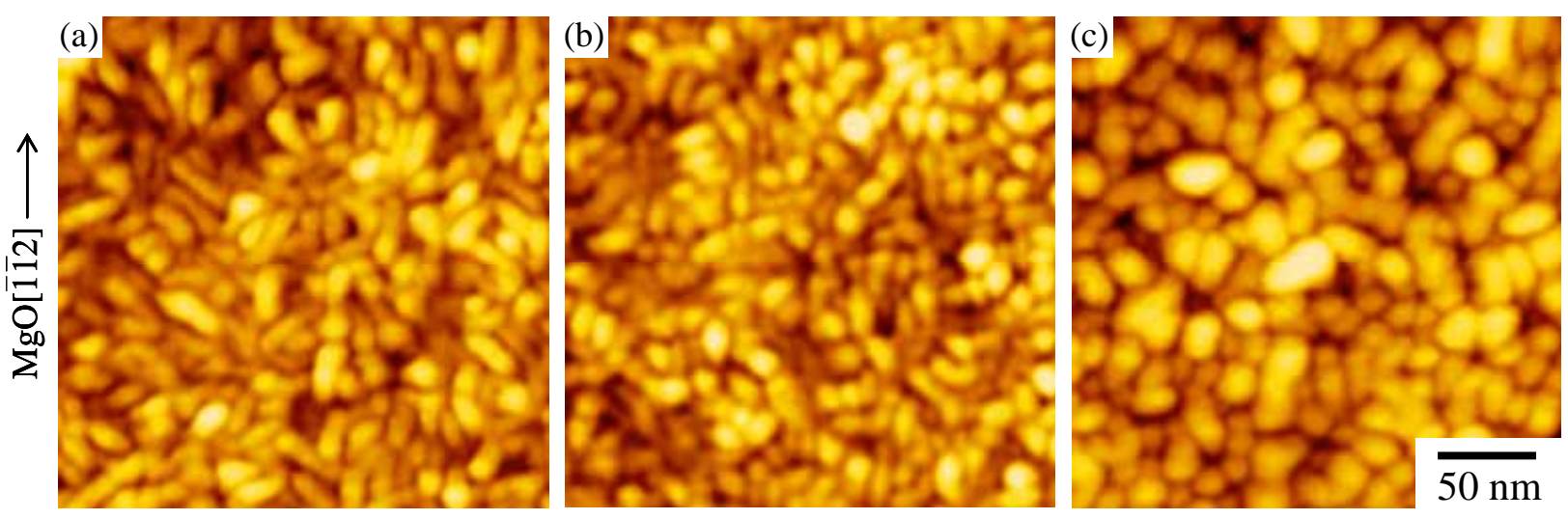

Fig. 19 AFM images of Fe thin films deposited on $\mathrm{MgO}(111)$ substrates at (a) $200{ }^{\circ} \mathrm{C}$, (b) $300{ }^{\circ} \mathrm{C}$, and (c) $400{ }^{\circ} \mathrm{C}$.

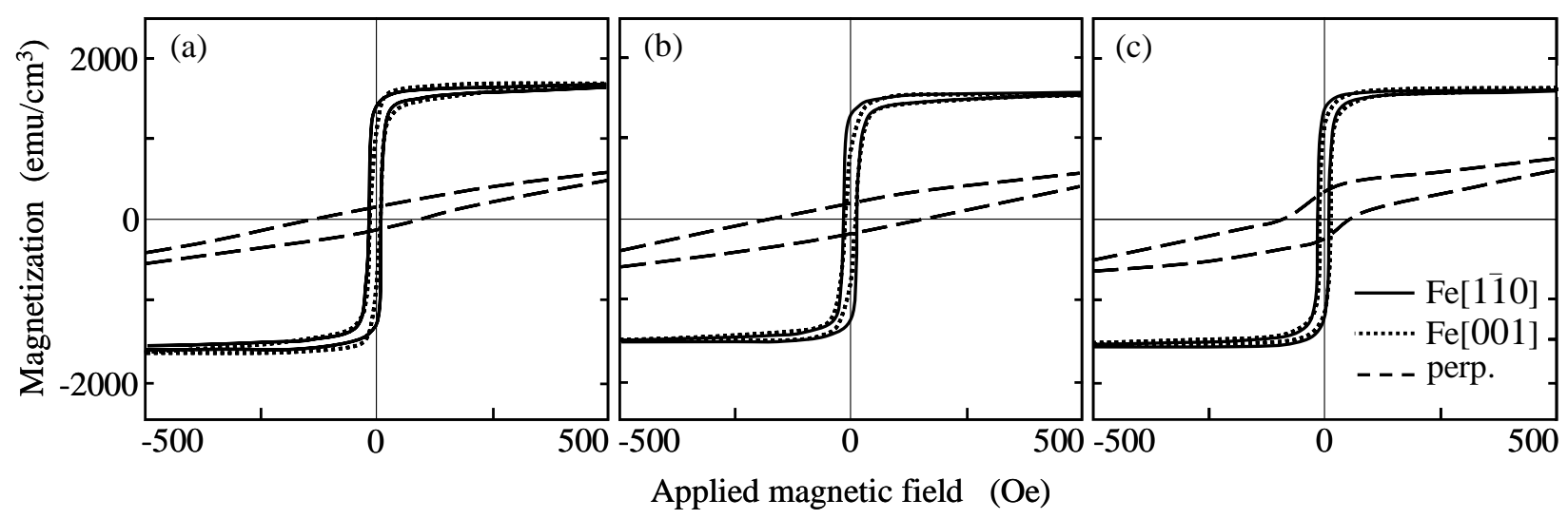

Fig. 20 Magnetization curves of Fe thin films deposited on $\mathrm{MgO}(111)$ substrates at (a) $200{ }^{\circ} \mathrm{C}$, (b) $300^{\circ} \mathrm{C}$, and (c) $400{ }^{\circ} \mathrm{C}$.

$\mathrm{Ru}(0001)^{22)}$ 上に形成されたFe薄膜に見られた $\mathrm{NW}, \mathrm{KS}$ 関係が， $\mathrm{MgO}(111)$ 基板上にFe薄膜を形成した場合でも出現することが分 かった、NW関係は 6 回対称であり 3 つのドメインが, KS関係 は6 回対称であり 6 つのドメインか存在し, $\mathrm{MgO}(111)$ 基板上にお けるFe(110)bc薄膜では合わせて 9 つのドメインか存在しているこ とになる . エピタキシャル方位関係は以下の通りである .

NW relationship: $\mathrm{Fe}(110)[001]_{b c} / / \mathrm{MgO}(111)[1 \overline{1} 0]$

KS relationship: $\mathrm{Fe}(110)[1 \overline{1} 1]_{\mathrm{bcc}} / / \mathrm{MgO}(111)[1 \overline{1} 0]$

$\mathrm{Fe}(110)$ boc面の $\mathrm{MgO}(111)$ 基板に対する格子ミスマッチは ,NW関係

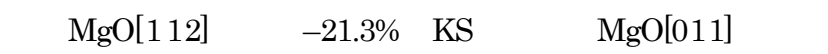
-16.5\%と大きな值となっている. Fig. 17 に基板温度 $300^{\circ} \mathrm{C}$ て形 成したFe薄膜の一連のRHEEDパターンを示す . 形成初期過程で は , $\mathrm{Fe}(110)_{\mathrm{boc}} \mathrm{MgO}(111)$ 界面に存在する大きなミスマッチのため 生じたと考えられるハロー状のRHEEDパターンか観察されたが， 膜厚 $2 \mathrm{~nm}$ 付近からNW及びKS関係に対応するFe(110)bc $の$ RHEEDパターンか観察され始めた . 基板温度を 200〜 $400{ }^{\circ} \mathrm{C} の$ 範囲て変化させてもRHEEDパターンの変化は同樣な傾向を示し た。

Fig. 18 にXRDパターンを示す. 基板温度 $400^{\circ} \mathrm{C}$ て形成した $\mathrm{Fe}$
薄膜において $\mathrm{MgO}(110)$ 基板の場合と同樣に, 特に強い $\mathrm{Fe}(220)_{\mathrm{bcc}}$ 反射か観察できる. 基板温度が $300{ }^{\circ} \mathrm{C}$, 及び $200{ }^{\circ} \mathrm{C}$ と低くなるに

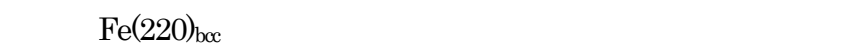
基板温度 $200{ }^{\circ} \mathrm{C}$ て形成したFe薄膜の(110)bc面間䛿は, バルク $\mathrm{Fe}$ に比べて $0.4 \%$ 小さくなっていることが分かった . 基板温度を $400{ }^{\circ} \mathrm{C}$ 程度まで上昇させると, バルク $\mathrm{Fe} に$ 近し格子間隔をとるこ とが分かった .

Fig. 19にMgO(111)基板上に形成したFe薄膜の表面形態を示す。 Fe 薄膜は Volmer-Weber 樣式でエピタキシャル成長しており， $\mathrm{NW}$ 及び KS 関係の薄膜成長に対応した 6 回対称性を持つ粒状の 構造か観察されている.基板温度の上昇に伴って粒径力増大して いることが汾かる。

Fig. 20 に磁気特性を示す.いずれの基板温度においても飽和磁 化值はバルク $\mathrm{Fe}$ 同樣であり，保磁力は $15 \mathrm{Oe}$ 程度であった . . ピタキシャルFe薄膜の面内ての磁気異方性は殆と”観察されなかっ た. $\mathrm{MgO}(111)$ 基板上に成長したエピタキシャルFe薄膜で， $\mathrm{NW}$ 及びKS関係により $9 つ の \mathrm{Fe}(110)_{\mathrm{boc}}$ ドメインか存在する、面内て磁 気異方性か観察されなかつたのは, これら 9 つのドメインの結晶 磁気異方性力重曽されているためと解积される。 


\section{4. まとめ}

異なる結晶面を持つ 3 種類の $\mathrm{MgO}$ 基板上に同樣の条件で $\mathrm{Fe}$ 薄 膜を形成し, $\mathrm{Fe}$ 薄膜の成長過程, 結晶構造, 表面形態及ひ磁気特 性を比較検討した .

$\mathrm{MgO}(100), \mathrm{MgO}(110), \mathrm{MgO}(111)$ 基板のいすれにおいてもエピ タキシャル Fe 薄膜か得られた. エピタキシャル方位関係は,

$\mathrm{Fe}(100)[011]_{\mathrm{bcc}} / / \mathrm{MgO}(100)[001]$

$\mathrm{Fe}(211)[1 \overline{1} \overline{1}]_{b c d} / \mathrm{MgO}(110)[1 \overline{1} 0], \mathrm{Fe}(211)[\overline{1} 11]_{\mathrm{bco}} / \mathrm{MgO}(110)[1 \overline{1} 0]$ $\mathrm{Fe}(110)[001]_{\mathrm{bod}} / \mathrm{MgO}(111)[1 \overline{1} 0], \mathrm{Fe}(110)[1 \overline{1} 1]_{\mathrm{bod}} / \mathrm{MgO}(111)[1 \overline{1} 0]$

であり， $\mathrm{MgO}(100)$ 面上では単結晶Fe(100) boc薄膜が , $\mathrm{MgO}(110)$ 面上ては膜面垂直方向に互いに $180^{\circ}$ 回転した関係を持つ双結晶 $\mathrm{Fe}(211)_{b c c}$ 薄膜が , $\mathrm{MgO}(111)$ 面上ではNW及ひKSの関係を持った 複合エピタキシャルFe(110)boc薄膜か得られた.RHEED及ひXRD を用いた解析により, 基板温度 $200 \sim 400^{\circ} \mathrm{C} て ゙ は$ 膜厚が $1 \mathrm{~nm}$ 以上 で良好な結晶性を持つエピタキシャル薄膜が成長すること，基板 温度力低い場合は膜面垂直方向の格子間塥ジ゙ル Feの值に比べ て $0.3 \sim 0.5 \%$ 程度小さくなる傾向か認められた . エピタキシャル Fe薄膜の磁気特性は, いずれの結晶面においても飽和磁化值はバ ルクFeと同樣であり，面内の磁気異方性は結晶磁気異方性を反映 していると解釈できた .

謝辞 本研究の一部は NEDO の補助を受けて行ったもの であり，ここに謝意を表します．

\section{References}

1) N. Inaba, Y. Uesaka, and M. Futamoto: IEEE Trans. Magn., $36,54(2000)$.

2) M. Ohtake, M. Futamoto, F. Kirino, N. Fujita, and N. Inaba: J. Appl. Phys. (2008) (in press).
3) T. Urano and T. Kanaji: J. Phys. Soc. Jpn., 57, 3403 (1988).

4) H. Fuke, A. J. Freeman, and T. Mizoguchi: Jpn. J. Appl. Phys., 32, L1137 (1993).

5) T. Handa, M. Ohtake, and M. Futamoto: IEICE Trans. Electron., E90-C 1565 (2007).

6) A. Subagyo, K. Sueoka, K. Mukasa, and K. Hayakawa: Jpn. J. Appl. Phys., 38, 3820 (1999).

7) J. M. Florczak and E. D. Dhlberg: Phys. Rev. B, 44, 9338 (1991).

8) B. Kardasz, J. Zukrowski, M. Przybylski, B. Heinrich, and J. Kirschner: J. Appl. Phys., 101, 09D110 (2007).

9) S. Yaegashi, T. Kurihara, and H. Segawa: J. Appl. Phys., 74, 4506 (1993).

10) K. T. Riggs and E. D. Dahlberg: J. Magn. Magn. Mater., 73, 46 (1988).

11) K. T. Riggs and E. D. Dahlberg: Phys. Rev. B, 41, 7088 (1990).

12) A. Subagyo, H. Oka, G. Eilers, K. Sueoka, and K. Mukasa: Jpn. J. Appl. Phys., 39, 3777 (2000).

13) H. Oka, A. Subagyo, M. Sawamura, K. Sueoka, and K. Mukasa: Jpn. J. Appl. Phys., 40, 4334 (2001).

14) J. A. Venable: Introduction to surface and thin film process (Cambridge Univ. Press, New York, 2000).

15) A. Nakamura and M. Futamoto: Jpn. J. Appl. Phys., 32, L1410 (1993).

16) A. Nakamura, M. Koguchi, and M. Futamoto: Jpn. J. Appl. Phys., 34, 2307 (1995).

17) G. Wasserman: Arch. Eisenhuettenwes, 16, 647 (1933).

18) Z. Nishiyama: Sci. Rep. Tohoku Univ., 23, 638 (1934).

19) G. Kurdjumov and G. Sachs: Z. Phys., 64, 325 (1930).

20) D.T. Dekadjevi, B. J. Hickey, S. Brown, T. P. A. Hase, B.D. Fulthorpe, and B. K. Tanner: Phys. Rev. B, 71, 054108 (2005).

21) M. T. Kief and W. F. Egelhoff: Phys. Rev. B, 47, 15 (1993).

22) S. Andrieu, M. Piecuch, and J. F. Bobo: Phys. Rev. B, 46, 15 (1992).

2007年10月4日受理，2008年2月14日採録 